\title{
Improving the electricity efficiency in South Africa through a benchmark-and- trade system
}

\author{
Roula Inglesi-Lotz ${ }^{*}$ and James N. Blignaut \\ Department of Economics, University of Pretoria, Pretoria, South Africa Main Campus, Hatfield, \\ Tukkiewerf Building, Pretoria 0002, South Africa \\ *Corresponding author. E-mail addresses: roula.inglesi-lotz@up.ac.za(R.Inglesi-Lotz), \\ jnblignaut@gmail.com (J.N.Blignaut).
}

\section{INTRODUCTION}

South Africa has undergone major political, social and economic changes during the past two decades. Partially, as a result of these, the country has begun to experience serious electricity supply shortages [1] and critical energy predicaments. The electricity crisis in 2008 was, among others, attributed to the mismatch between the supply and the demand for electricity and affected the whole economy considerably [2].

The South African policy makers make efforts to bring the demand and supply in a certain equilibrium by not only, boosting the electricity generation in the country (two new power plants to be operative in 2015), but also promoting Demand-Side Management (DSM) initiatives through Eskom - the national supplier. In this paper, we wish to explore another DSM method that will give incentives for more efficient use of electricity to all the economic sectors of the country. This system will particularly encourage electricity-intensive sectors to save electricity in order to avoid the cost-related and environmental consequences resulting from the use of electricity.

A cap- (or our chosen term, benchmark ${ }^{1}$ ) and-trade system as used internationally has a primary objective to steadily improve the environmental performance of a country by decreasing its emissions in a cost-effective manner [3]. As such the concept of cap-and-trade is neither recent nor new. This type of

1 The only difference between the two terms is the manner of determination of the maximum amount of the targeted indicator which the participants are allowed to emit. In a cap-and-trade system, the cap is determined based on a number of factors such as previous performance or more usually the country's overall performance goal. On the other hand, in a benchmark-and-trade system, the amount is determined by comparing ("benchmarking") the country or participant to other countries or participants. 
system has been used for different types of emission such as $\mathrm{SO}_{2}$ and $\mathrm{CO}_{2}$ as well as for greenhouse gas emissions (GHG) in general at a global level. Table 1 summarises the information on the most important applications of cap-and-trade systems around the world since the 1980s.

Table 1: Main cap-(benchmark)-and-trade systems since the 1980s

\begin{tabular}{|c|c|c|c|c|}
\hline Programme & Year & Place & Focus & Goal \\
\hline $\begin{array}{l}\text { Leaded Gasoline Phasedown } \\
\text { Program }\end{array}$ & $1980 \mathrm{~s}$ & United States & Gasoline & $\begin{array}{l}\text { Production of gasoline with a } \\
\text { lower lead content }\end{array}$ \\
\hline US Clean Air Act Amendments & 1990 & United States & $\begin{array}{l}\mathrm{SO}_{2} \text { and } \\
\mathrm{NO}_{2}\end{array}$ & $\begin{array}{c}\text { Reducing } \mathrm{SO}_{2} \text { to } 50 \% \text { of } 1980 \\
\text { by } 2000\end{array}$ \\
\hline $\begin{array}{c}\text { Regional Clean Air Incentives } \\
\text { Market (RECLAIM) }\end{array}$ & 1994 & Los Angeles air basin & $\begin{array}{l}\mathrm{NO}_{x} \text { and } \\
\mathrm{SO}_{x}\end{array}$ & $\begin{array}{l}\text { Reducing emissions by } 70 \% \text { by } \\
2003\end{array}$ \\
\hline $\begin{array}{l}\text { Acid rain program - US } \mathrm{SO}_{2} \\
\text { Trading Program }\end{array}$ & 1995 & United States & $\mathrm{SO}_{2}$ & $\begin{array}{c}\text { Reducing } \mathrm{SO}_{2} \text {-emissions by } \\
50 \% \text { of } 1980 \text { by } 2000\end{array}$ \\
\hline $\begin{array}{l}\text { North-eastern } \mathrm{NO}_{x} \text { Budget } \\
\text { Program }\end{array}$ & 1999 & $\begin{array}{l}\text { USA: } 12 \text { north- } \\
\text { eastern states and } \\
\text { the District of } \\
\text { Columbia }\end{array}$ & $\mathrm{NO}_{x}$ & $\begin{array}{l}\text { Reducing emissions to } 25 \% \text { of } \\
1990\end{array}$ \\
\hline $\begin{array}{c}\text { European Emissions Trading } \\
\text { System }\end{array}$ & 1998 & $30 \mathrm{EU}$ countries & $\begin{array}{c}\text { GHG } \\
\text { emissions }\end{array}$ & $\begin{array}{l}\text { Reducing EU's GHG emissions } \\
\text { (each EU member sets its own } \\
\text { target, subject to review by } \\
\text { the European Commission) }\end{array}$ \\
\hline $\mathrm{NO}_{x}$ Budget Program (SIP) & 2003 & USA: 22 states & $\mathrm{NO}_{\mathrm{x}}$ & $\begin{array}{l}\text { Reducing the transport of } \\
\text { ozone pollution over broad } \\
\text { geographic regions }\end{array}$ \\
\hline
\end{tabular}

Sources: $[4,5,6,7,8,9,10,11]$

These systems have three main elements: a) the cap, b) the tradable allowances, and c) the formula for distributing the allowances [12]. The regulator of the system sets the total amount of emissions the participants are allowed to release, the "cap", for a specific time period. Then, it allocates credits ("permits" or "allowances"), to the participants usually equal to the size of the cap. One way of doing this is to estimate the allowances relative to contributions to total emissions in a selected base year and then freely distribute them. Alternatively, the participants receive allowances based on their historical emissions adjusted for the specific system's commitment [10]. The allowed emissions can remain constant or be updated frequently [13]. Another way to allocate credits is auctioning. It is mainly preferred to other ways because the price of credits acts as a motivation for consumers to reduce their energy usage [14].

The regulated entities can then either use their allowances or trade it among themselves [6]. The participants that emit less than their allowance can sell their credits (permits or allowances) to those 
that are not able to easily cut their emissions in the short-run or for those that the cost for reduction of emissions varies [3]. The system thus rewards the participants that were already doing better than their cap and the ones that managed to improve their emissions. From an economic viewpoint, the aim of a cap-and-trade system is to internalise the externality of the emissions by creating a market that puts a price on the emissions [15].

Choosing the target indicator is the most important aspect of any cap-and-trade system as it defines both the character and the objective of such a system. As indicated above, there are various systems that target $\mathrm{CO}_{2}, \mathrm{SO}_{2}$ or other $\mathrm{GHG}$ emissions. With these indicators targeted, the systems deal with the harmful atmospheric results of fossil fuel-based energy consumption. While these systems do have merit, we developed a system based on the principles and practices of cap-and trade systems but focused on the cause, and not on the effect, which is primarily the combustion of coal, with specific reference to electricity consumption in South Africa [16].

Taking this into account, the proposed system aspires towards the reduction of electricity consumption without ignoring the decisions regarding the participants' economic output. Hence, the system's main objective is the reduction of electricity intensity of the South African industrial sectors, with electricity intensity being defined as the ratio between the electricity consumption of the sector and its output. In the proposed system, the benchmark chosen is the average electricity intensity of the OECD members for each industrial sector. The group of OECD countries is selected as they comprise some of South Africa's most important trade partners and they represent a pool of countries that aspire towards applying international 'best practices'. Moreover, the South African electricity sector resembles that of advanced economies and, hence, needs to be compared against the OECD countries given their level of industrialisation and sophistication within this sector.

This paper is structured as follows: the next section presents and discusses thoroughly the proposed system and its design. Following, a primitive application of the system is presented using South African data for 2006 and a comparison of the results with the implementation of a carbon tax. The last section gives a conclusion.

\section{PROPOSED BENCHMARK-AND-TRADE SYSTEM}

Taking into account the important and desirable principles of administration ease and transparency, the proposed system suggests a straightforward method to determine the credits to be traded, after having 
identified the targeted indicator to be the electricity intensity of the participants (as discussed in the introduction). Using a grand-fathering method, the regulator allocates credits to each sector per phase ${ }^{2}$ based on their performance during the previous phase. Although, Hahn and Stavins [17] have supported independence between the initial and final allocation of allowances, they also show that in particular programmes such as the one proposed here in practice, independence is not supported and past performance is taken into consideration. For every percentage of difference between the South African and the benchmark's electricity intensity, one credit is assigned (either to be supplied or demanded by the sector).

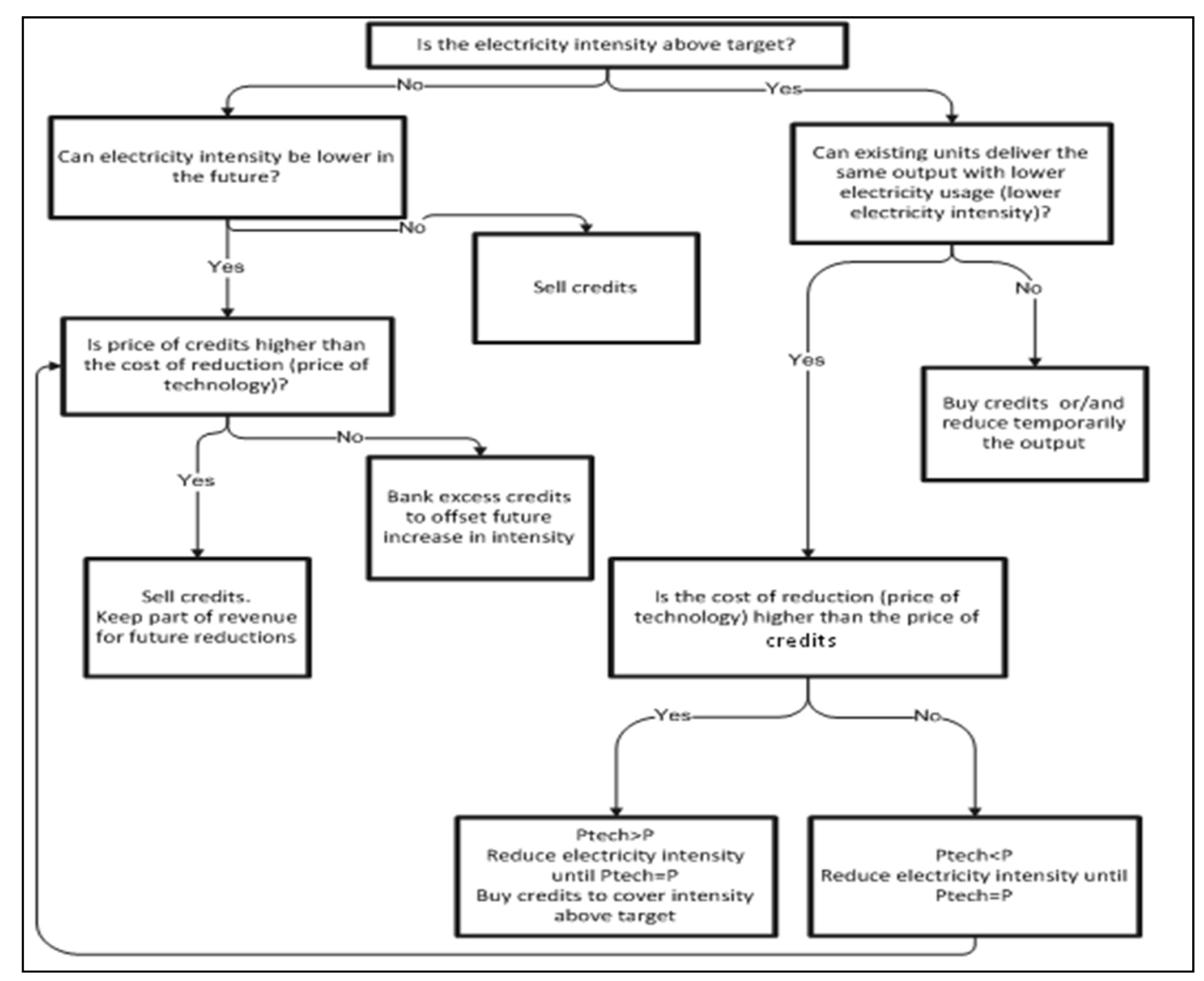

Figure 1: Participants' decision-tree in the proposed benchmark-and-trade system

Based on the traditional decision-making tree for benchmark-and-trade systems [18], Figure 1 presents a diagrammatic representation of the decisions which a participant in the proposed system faces. The first question to be answered is of strategic importance because it classifies the sector as a 'buyer' or

$2 \mathrm{~A}$ phase is defined as a predetermined time period at the end of which a participant's performance is evaluated. 
'seller' of credits. In case the electricity intensity is above (below) target, which means that South Africa is worse (better) off, the sector will act as a buyer (seller) in the trade.

Next, the participant, either a buyer or a seller, faces a question about its potential to reduce its electricity intensity further in the future. This question's significance lies in the fact that this system aims to improve the sectors' electricity efficiency levels without affecting their economic output. Finally, the participants are concerned with the cost of reduction or the price of technology needed to decrease the levels of electricity intensity. It can be explained as the cost to a sector or a company to replace its current production methods with newer, more advanced and more efficient technologies. This cost can vary from one time period to another depending on various factors such as the openness of the economy that will allow the transfer of new technologies. Moreover, in high levels of efficiency, even better technologies become scarce and hence, more expensive. The price of technology is a contributing and key factor to the representation of the total supply curve of credits. However, an average cost for all technologies for all sectors would be an unreal representation of the reality and also very difficult to estimate.

The overall relationship of the price and the quantity of credits supplied follows basic economic theory: the higher the price, the higher the quantity supplied. However, the behaviour of the sellers (suppliers) changes depending on price of the technology compared to the price of the credits. For as long as the price of the credits is lower than the price of technology, the supply curve is relatively inelastic (see Figure 2 - for all cases). That is, for every given increase in price, the increase of quantity supplied is smaller $(-1<\mathrm{e}<0)$. When this inequality holds, the suppliers lack incentives to sell credits because the revenue from the sales cannot cover the potentially desirable change in technology. Conversely, if the price of credit becomes higher than the price of technology, the suppliers react with higher increases of the quantity supplied for the same percentage increases of price (supply curve relatively elastic, $-\infty<\mathrm{e}<-$ 1). If this inequality holds the suppliers have additional motivation to sell credits in order to achieve profits. 

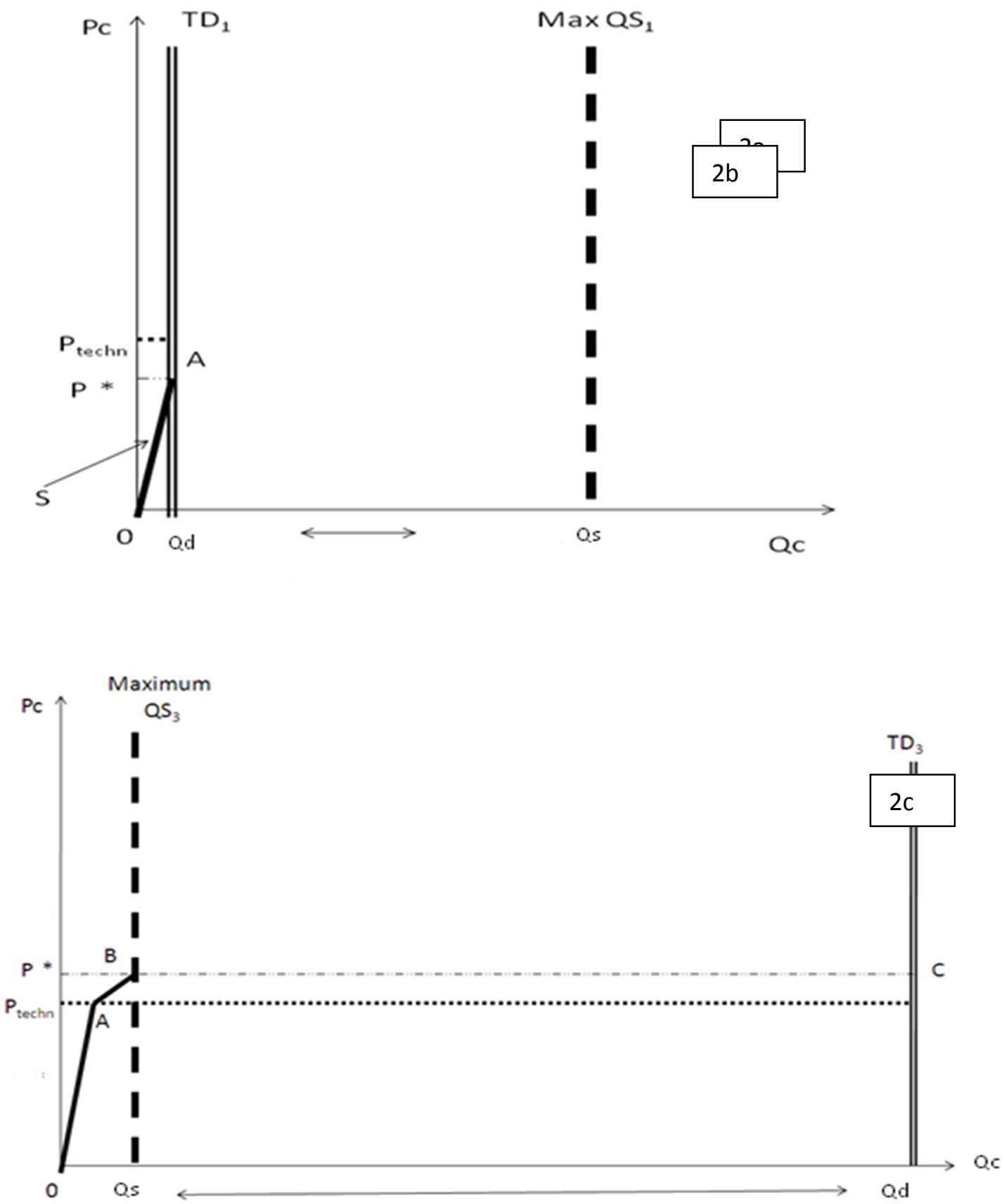

Figure 2: Total demand and supply of credits/allowances

Note: Figure 2a presents the case where the demand for credits is lower than the maximum supply of credits and the maximum demand is at Qd where the elasticity of supply has changed. Figure $2 \mathrm{~b}$ presents the case where demand for credits is again lower than the maximum supply of credits but the maximum demand is low (before the change in the slope of the supply curve). Finally, Figure $2 c$ illustrates the case where the demand for credits is higher than the maximum supply of credits. 
It can also be seen that the supply cannot increase indefinitely. This is due to the method of determining the credits based on their difference to the OECD industrial sectors' electricity intensity: there are a specific number of credits to be traded in the market. In order to be able to determine the price of the credits, the total demand curve is also required. Contrary to the supply, the total demand of credits is constant and independent of the price. The sectors whose electricity intensity is higher than the benchmark are obliged to buy the necessary credits as a form of a fine for their performance. Hence, the quantity demanded in the market is constant (see Figure 2 - for all cases).

Figure 2 represents the market including both total supply and demand curves to show how the price of the electricity intensity credits is determined. The equilibrium price $\left(P^{*}\right)$ is depicted at point $E$ where the total demand and supply curves cross each other. In other words, that is the maximum price that the consumers (buyers) are prepared to pay per credit. The system applies first-degree price discrimination, which is defined as the situation "when each consumer is charged the maximum price he or she is prepared to pay for each unit of the product" [19]. Hence, the price in this simple equilibrium is $\mathrm{P}^{*}$ for each credit.

The situation presented in Figure $2 \mathrm{a}$ is not the only possible setup in such a benchmark-and-trade system. Depending on the standard chosen, the constant demand curve might cross the supply curve before the point where elasticity changes (Figure $2 b$ ). That would mean that the equilibrium price (maximum price consumers are prepared to pay) would be lower than the price of technology. It is also likely that the total demand curve is on the right side of the line showing the maximum quantity supplied (Figure 2c). In that situation, a shortage of credits will exist since the amount of credits that can be supplied in the market cannot cover the demand for credits, in which case the regulator is responsible for providing the consumers with credits at least at price $\mathrm{P}^{*}$.

\section{Application of proposed model to the South African case}

Here we apply South African and the OECD electricity intensity data, assuming 2006 is the starting year of Phase 1. We model the plausible impact of various scenarios pertaining to different electricity intensity targets based on actual country and sectoral electricity intensity data. These scenarios are hypothetical but they do provide insight as to the likely outcome of a real market situation.

The difference between the sectoral intensities of South Africa and the OECD is substantial and could possibly not be covered in one phase. Hence, different scenarios for Phase I of the system are proposed. 
The benchmarks after the implementation of Phase I will have to be re-estimated taking into account the progress both the South African and the OECD sectors made.

Each standard is a proposition on how the trade will be in Phase I. The standards to be discussed are as follows:

- Standard 1: 20 times the OECD electricity intensity

- Standard 2: 10 times the OECD electricity intensity

- Standard 3: OECD electricity intensity

Regarding the price of the credits, the main scenario assumes that it is equal to the carbon tax on electricity generated imposed by the South African government of R0.02/kWh consumed; while the other two scenarios assume conditions where the price is lower and higher than the carbon tax by $\mathrm{R} 0.01 / \mathrm{kWh}$, respectively.

Based on these scenarios/standards, we investigate the savings in electricity consumption and in monetary terms from the implementation of a benchmark-and-trade system where all the economic sectors of the country participate.

\subsection{Data}

In order to calculate the targeted indicator for the specific application, we define electricity intensity as the electricity consumption (total or per sector) divided by the Gross Domestic Product (GDP) (overall economy or sectoral $[20,21]$

One part of this exercise would be to compare the South African data with the OECD countries that were selected as the benchmark. Information for total and sectoral electricity consumption was derived from the Energy Balances for OECD countries [22] and Energy Balances for non-OECD countries [23]. Data from national sources might have been more accurate but by using the OECD documents we ensure that all the countries' variables are measured in the same way. National data for GDP, CPI and PPP for all countries were derived from the World Economic Outlook April 2010 of the International Monetary Fund (IMF) [24]. The disaggregated sectoral data for economic output were derived from the STAN Database for structural analysis of OECD. 


\subsection{Differences between South Africa and OECD electricity intensity}

In Table 2, the difference between the South African industrial sectors' electricity intensity levels and their OECD counterparts is presented, according to the standard chosen. As discussed in the theoretical representation, one percentage is equivalent to one credit. Also, a negative (positive) sign shows that the South African sector is more (less) intensive than the standard chosen, hence it will become a consumer (supplier) of credits in the trade.

Table 2: Difference of electricity intensities (South Africa - Standards) in 2006*

\begin{tabular}{lccc}
\hline & \multicolumn{3}{c}{ Standards } \\
Sectors & $\mathbf{1}$ & $\mathbf{2}$ & $\mathbf{3}$ \\
\hline Agriculture and forestry & $\mathbf{1 \%}$ & $-97 \%$ & $-1871 \%$ \\
Basic metals** & $\mathbf{5 1 \%}$ & $\mathbf{1 \%}$ & $-887 \%$ \\
Chemical and petrochemical & $\mathbf{7 0 \%}$ & $\mathbf{4 1 \%}$ & $-495 \%$ \\
Construction & $\mathbf{1 0 0 \%}$ & $\mathbf{1 0 0 \%}$ & $\mathbf{9 8 \%}$ \\
Food and tobacco & $96 \%$ & $\mathbf{9 1 \%}$ & $\mathbf{1 1 \%}$ \\
Machinery & $99 \%$ & $\mathbf{9 8 \%}$ & $\mathbf{8 1 \%}$ \\
Mining and quarrying & $-20 \%$ & $-141 \%$ & $-2306 \%$ \\
Non-metallic minerals & $-31 \%$ & $-162 \%$ & $-2518 \%$ \\
Paper, pulp and printing & $\mathbf{5 0 \%}$ & $\mathbf{1 \%}$ & $-891 \%$ \\
Textile and leather & $\mathbf{6 8 \%}$ & $\mathbf{3 5 \%}$ & $-549 \%$ \\
Transport equipment & $\mathbf{9 6 \%}$ & $\mathbf{9 2 \%}$ & $\mathbf{2 0 \%}$ \\
Transport sector & $\mathbf{6 7 \%}$ & $\mathbf{3 4 \%}$ & $-563 \%$ \\
Wood and wood products & $\mathbf{8 7 \%}$ & $\mathbf{7 5 \%}$ & $-154 \%$ \\
\hline
\end{tabular}

Notes: *Number in bold (positive sign) show that the sector is better off than the benchmark chosen and hence they are suppliers of credits and the non-bold numbers (negative sign) indicate that the sector's intensity is higher than the benchmark's and therefore, the sector is a consumer of credits.

** 'Iron and steel' and 'non-ferrous metals'

It can be seen that a number of sectors (i.e. 'construction', 'food and tobacco', 'machinery' and 'transport equipment') remain suppliers in the trade regardless of the benchmark chosen. Sectors such as 'mining and quarrying' and 'non-metallic minerals' have performed worse than all the proposed selected benchmarks and hence, they are the consumers of the market. However, the rest of the sectors change roles according to how strict the chosen benchmark is. For instance, 'agriculture' acts as a 
supplier under Standard 1. Under Standards 2 and 3, however, it is more electricity intensive than the selected benchmarks and therefore it plays the role of a consumer in the market.

In a benchmark-and-trade system, the participants are free to decide whether they prefer to trade in the market or to rather reduce their electricity intensity in order to meet the proposed benchmark. However, in the next phase even the sectors that preferred to participate fully in the trade have an economic incentive to reduce their electricity intensity. Also, a number of sectors will combine the two options, trading some credits and adjusting their electricity intensity accordingly.

\subsection{Results of South African model}

Next, the first case is presented where all the sectors participate willingly in the market without changing their electricity intensity behaviour. Subsequently, the results of the situation where all the sectors decide to alter their consumption in order to meet the benchmark chosen are presented. After translating the differences into credits, one can calculate the total demand of electricity intensity credits and the maximum credits to be supplied in the benchmark-and-trade market. Table 3 summarises the total supply and demand of credits for each of the standards.

Table 3: Total demand and supply of credits in 2006 for different standards implemented

\begin{tabular}{lccc}
\hline & $\mathbf{1}$ & $\mathbf{2}$ & $\mathbf{3}$ \\
\hline Total demand (TD) & 51 & 399 & 10233 \\
Total supply (TS) & 785 & 567 & 211 \\
Difference (TS-TD) & 734 & 168 & -10022 \\
& surplus & surplus & shortage \\
\hline
\end{tabular}

It can be seen that the stricter the benchmark (e.g. Standard 3), the less sectors are able to supply the market with credits; while for more lenient benchmarks (e.g. Standard 1), the majority of the South African industrial sectors are better off than the benchmark. The opposite holds for the total supply: the stricter the benchmark, the lower the total supply for credits.

To account for possible decreases in production to meet the efficiency requirements of the system, a strong assumption is held from now on: economic output of the sectors remains the same and hence, the sectors can only improve their intensity by reducing their electricity consumption. In the proposed 
system, the differences between South Africa and the OECD can be translated into units of energy. Table 4 presents the differences per sector converted into GWh.

Table 4: Changes in electricity use to be implemented to reach the benchmarks (GWh)*

\begin{tabular}{lccc}
\hline Sectors & Standard 1 & Standard 2 & Standard 3 \\
\hline Agriculture and forestry & 85.09 & $-5,668.08$ & $-109,225.09$ \\
Basic metals ** & $11,966.39$ & 300.62 & $-209,683.27$ \\
Chemical and petrochemical & $7,085.10$ & $4,087.00$ & $-49,878.90$ \\
Construction & 58.09 & 58.03 & 56.93 \\
Food and tobacco & 722.42 & 688.88 & 85.26 \\
Machinery & 46.08 & 45.65 & 37.79 \\
Mining and quarrying & $-5,727.07$ & $-39,691.77$ & $-651,056.50$ \\
Non-metallic minerals & -804.59 & $-4,214.29$ & $-65,589.03$ \\
Paper, pulp and printing & 885.56 & 14.98 & $-15,655.33$ \\
Textile and leather & 353.57 & 183.8 & $-2,872.15$ \\
Transport equipment & 89.32 & 85.61 & 18.72 \\
Transport sector & $2,261.82$ & $1,139.30$ & $-19,065.97$ \\
Wood and wood products & 264.04 & 225.7 & -464.37 \\
\hline Economy-wide & $17,285.82$ & $-42,744.54$ & $-1,123,291.91$ \\
\hline
\end{tabular}

Notes: *The negative sign indicates that the sector will have to save this amount of electricity consumption while the positive sign shows that the sector can increase its electricity consumption and still be within the set benchmark.

** 'Iron and steel' and 'non-ferrous metals'

For a better understanding of Table 4, the 'agricultural' sector is discussed as an example. The electricity consumption of the agricultural sector in 2006 (hypothetical starting year of the system) was 5838 260GWh and its intensity was 0.320GWh/\$millions (PPP adj). In the same year, the OECD average electricity intensity was $0.316 \mathrm{GWh} / \$$ millions (adjusted PPP). Therefore, the difference between the two was $-1 \%$ and the sector will act as a supplier of credits. If the economic output of the sector remained unchanged, then these credits would all be converted into GWh by finding the $1 \%$ difference of the total electricity consumption: $1 \% * 5838260 \mathrm{GWh}=85$ 092GWh.

Looking at the overall picture, 'mining and quarrying' and 'non-metallic minerals' are the only consumers of credits in the market. When employing a stricter standard, such as Standard 2, the 'agriculture' sector also joins the group of consumers while eventually, under Standard 3, the only suppliers in the market are 'construction', 'food and tobacco', 'machinery' and 'transport equipment'. 
However, the size of the gain or loss of each sector by its participation in the system is dependent on the price of the credit. Given the fact that the market has not been in effect before, it is difficult to have absolutely realistic price scenarios. However, the baseline scenario can adopt the carbon tax for electricity generation in South Africa that was proposed to be R0.02/kWh (for the other two scenarios, a price lower and a price higher than the tax are selected for a better view of a range of results).

Table 5 presents the possible savings or expenses in ZAR millions per sector if all the sectors decide not to change their consumption behaviour but purchase or sell credits in the market.

Continuing with the example of the 'agricultural' sector, by being more efficient than the OECD counterpart when selecting Standard 1, it will have savings that will vary from ZAR 0,85-2,55 million (depending on the price). However, when Standard 2 is selected, the 'agricultural' sector is more intensive than the OECD; therefore, it is a buyer of credits and eventually it would have to pay between ZAR 56.68 million and ZAR170.04 million in order to acquire the required credits. Under Standard 3, the 'agricultural' sector is much more intensive than the selected benchmark. Hence, the expenses of the sector to acquire the necessary credits are higher than in Standard 2.

\section{Benchmark-and-trade or carbon tax}

Taking these findings into account, we proceed with a comparative exercise between the proposed benchmark-and-trade system and a carbon tax. Regarding the economic benefit for the electricity users, Table 6 presents the savings and expenses of the various sectors under the scenario of a carbon tax of R0.02/kWh versus the three different standards of the proposed system when the price of the credits is equal to the carbon tax (columns (2)-(5)).

In the case of a carbon tax, the economic sectors will have to pay a certain amount of tax for their electricity usage. However, in the case of the benchmark-and-trade system (depending on the benchmark selected), some sectors will gain from the trade and will be able to cover some of their costs during the period of implementation. For instance, the 'agricultural' sector will have to pay ZAR116.5 million to the government if taxation is implemented. However, if Standard 1 of the benchmark-andtrade system is chosen the sector will be considered as one of the suppliers of the trade and it will gain ZAR1.7 million. The situation would change in case Standard 2 is chosen: the sector is now a consumer of credits in the market and it would have to spend ZAR113.36 million in order to buy the necessary 
Table 5: Savings and expenses of the participating sectors (in ZAR millions)*

\begin{tabular}{|c|c|c|c|c|c|c|c|c|c|}
\hline \multirow[b]{2}{*}{ Sectors } & \multicolumn{3}{|c|}{ Standard 1} & \multicolumn{3}{|c|}{ Standard 2} & \multicolumn{3}{|c|}{ Standard 3} \\
\hline & R0.01/kWh & R0.02/kWh & R0.03/kWh & R0.01/kWh & R0.02/kWh & R0.03/kWh & R0.01/kWh & $\mathrm{R} 0.02 / \mathrm{kWh}$ & R0.03/kWh \\
\hline Agriculture \& forestry & 0.85 & 1.7 & 2.55 & -56.68 & -113.36 & -170.04 & $-1,092.25$ & $-2,184.50$ & $-3,276.75$ \\
\hline Basic metals** & 119.66 & 239.33 & 358.99 & 3.01 & 6.01 & 9.02 & $-2,096.83$ & $-4,193.67$ & $-6,290.50$ \\
\hline Chemical \& petrochemical & 70.85 & 141.7 & 212.55 & 40.87 & 81.74 & 122.61 & -498.79 & -997.58 & $-1,496.37$ \\
\hline Construction & 0.58 & 1.16 & 1.74 & 0.58 & 1.16 & 1.74 & 0.57 & 1.14 & 1.71 \\
\hline Food \& tobacco & 7.22 & 14.45 & 21.67 & 6.89 & 13.78 & 20.67 & 0.85 & 1.71 & 2.56 \\
\hline Machinery & 0.46 & 0.92 & 1.38 & 0.46 & 0.91 & 1.37 & 0.38 & 0.76 & 1.13 \\
\hline Mining \& quarrying & -57.27 & -114.54 & -171.81 & -396.92 & -793.84 & $-1,190.75$ & $-6,510.56$ & $-13,021.13$ & $-19,531.69$ \\
\hline Non-metallic minerals & -8.05 & -16.09 & -24.14 & -42.14 & -84.29 & -126.43 & -655.89 & $-1,311.78$ & $-1,967.67$ \\
\hline Paper, pulp \& printing & 8.86 & 17.71 & 26.57 & 0.15 & 0.3 & 0.45 & -156.55 & -313.11 & -469.66 \\
\hline Textile \& leather & 3.54 & 7.07 & 10.61 & 1.84 & 3.68 & 5.51 & -28.72 & -57.44 & -86.16 \\
\hline Transport equipment & 0.89 & 1.79 & 2.68 & 0.86 & 1.71 & 2.57 & 0.19 & 0.37 & 0.56 \\
\hline Transport sector & 22.62 & 45.24 & 67.85 & 11.39 & 22.79 & 34.18 & -190.66 & -381.32 & -571.98 \\
\hline Wood \& wood products & 2.64 & 5.28 & 7.92 & 2.26 & 4.51 & 6.77 & -4.64 & -9.29 & -13.93 \\
\hline Economy-wide & 172.85 & 345.72 & 518.56 & -427.43 & -854.9 & $-1,282.33$ & $-11,232.9$ & $-22,465.84$ & $-33,698.75$ \\
\hline
\end{tabular}

Notes: *The positive figures indicate the amounts in ZAR millions that the sectors will be able to receive from the participation in the market while the negative figures show the amounts that the sectors will have to spend because they are more intensive than the benchmark chosen.

** 'Iron and steel' and 'non-ferrous metals' 
Table 6: Comparison of financial and electricity impact of carbon tax and benchmark-and-trade to various sectors (2006).

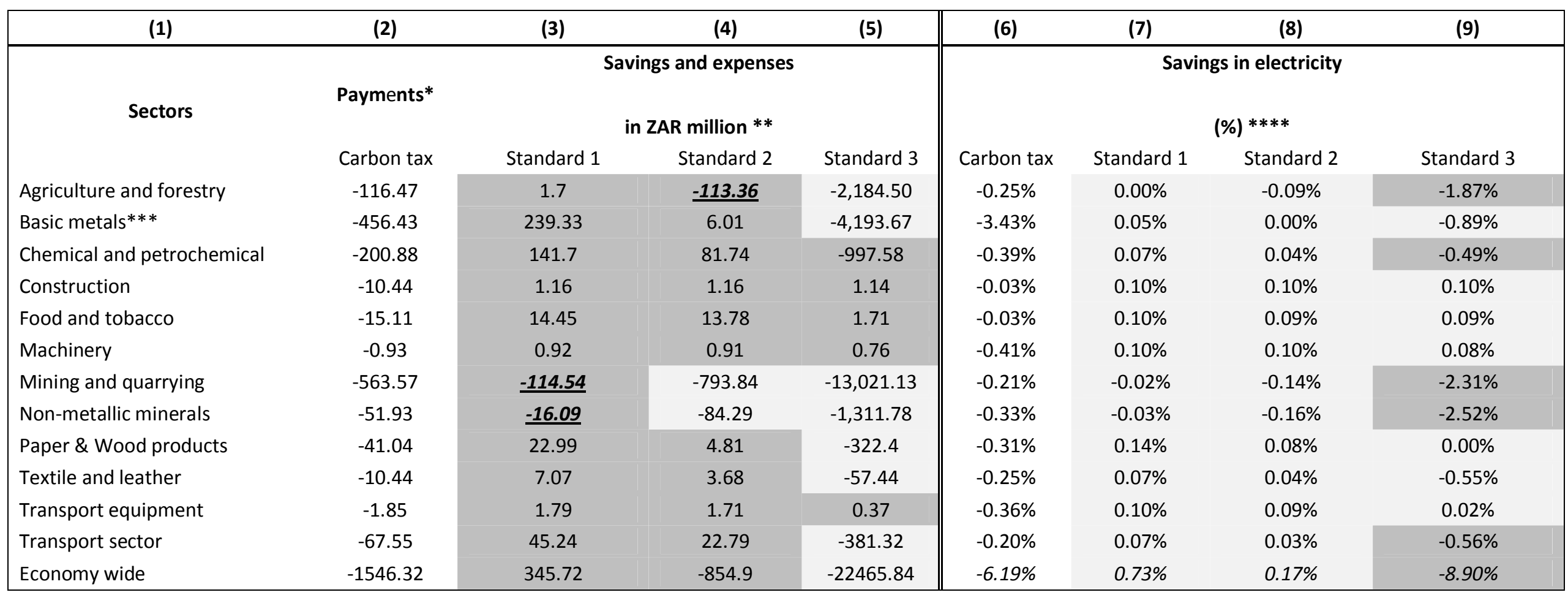

Notes: *The estimates for the savings in electricity after a carbon tax implementation are from a CGE application. These results and the benchmark-and-trade system's results are time-neutral reflecting results by sector at the end of an undefined period. Also, the benchmark-and-trade system does not include feedback effects from the residential and commercial sectors or from inter-industry relations while the CGE does.

**The negative signs in the "savings and expenses" indicate consumer-sectors that need to spend these specific amounts; while the positive signs indicate supplier-sectors that receive these amounts from their participation in the market. The dark grey cells show that the standard chosen under a benchmark-andtrade system is better off the case of a carbon tax implementation and the light grey cells show that the standard chosen is worse off.

$* * *$ 'Iron and steel' and 'non-ferrous metals'

****The negative signs indicate consumer-sectors that need to reduce their electricity usage; while the positive signs indicate supplier-sectors that can even increase their consumption if they choose too. The dark grey cells show that the standard chosen under a benchmark-and-trade system is better off in the case of a carbon tax implementation and the light grey cells show that the standard chosen is worse off 
credits to continue consuming the same amount of electricity. It is important to note that although the sector is a consumer of credits and has to spend, the amount is lower than the alternative of taxation.

On the other hand, the participants may decide not to buy or sell electricity efficiency credits but rather adjust their electricity consumption accordingly in order to reach the chosen benchmark. In addition, Table 6 presents the decreases of electricity after the implementation of a carbon tax (column (6)) and the percentage change needed in each sector to reach the standard in the benchmark-and-trade system (columns (7)-(9)).

Based on these results, it can be seen that when using Standards 1 and 2 all the sectors are better off compared to the reductions expected from the implementation of a carbon tax of R0.02/kWh. However, under a stricter benchmark, a number of sectors would have to decrease their electricity consumption substantially more than under taxation. The economy-wide electricity usage may be expected to decrease by up to $8.9 \%$, higher than the carbon tax case of $6.19 \%$.

\section{Conclusion}

After appreciating the importance of benchmark-and-trade systems in general, this paper proposed a benchmark-and-trade system with the main purpose of improving electricity efficiency levels in South Africa by using a market-based sectoral approach. In the country, a high proportion of electricity generation is based on coal burning with detrimental effects to the $\mathrm{CO}_{2}$ and other emissions of the country. Hence, the initial idea of a benchmark-and-trade system was to reduce the electricity consumption (which is proportional to the generation) of the country. However, such a target could affect the country's economic output severely. Therefore, the proposed system's uniqueness lies with the fact that it chooses rather to target the reduction of an indicator that takes into account the total and sectoral economic output: the intensity of electricity usage.

The key finding was that depending on the chosen benchmark, the price of the credits traded would be different. Another important point is that the price of technology is a crucial factor for the participants' decision to change their production methods to more electricity efficient ones. The comparison with the carbon tax alternative showed that a benchmark-and-trade system's success and superiority in South Africa is highly dependent on the choice of the benchmark. With the scenarios here, it was shown that under the proposed system there will always be sectors that profit from it by being the suppliers of credits. Conversely, under taxation, all the sectors will have to increase their expenses. However, if the 
system is well-designed and correctly implemented, energy intensive sectors such as mining will have to pay considerably less to buy credits than paying the equivalent tax.

Finally, if the participants of the proposed system decide not to buy or sell credits but rather adjust their electricity consumption to match the chosen benchmark, then there would be no financial gains but only a positive effect on the country's electricity consumption. In this case, a strict benchmark can achieve higher electricity savings than the implementation of a carbon tax system.

To conclude, this system has shown the potential in efficiency gains as well as the financial benefits for the participants compared to a carbon tax. Possible limitations of the system can be considered the moving target of the OECD average countries as well as the risk by choosing the most appropriate Standard that will most certainly affect the results. The findings of a Computable General Equilibrium (CGE) study by Goulder et al. [25] also confirm that "Effects on profits depend critically on the relative reliance on auctioning or free allocation of allowances".

Due to its generic and simple approach this system could be implemented in various countries with similar economic structure and energy profile as South Africa. As a final note, this system should be part of a holistic and concerted effort to reduce a country's energy intensity and not the only instrument used, as also suggested by Hanemann [26].

\section{REFERENCES}

[1] Inglesi-Lotz, R., \& Blignaut, J. (2011). South Africa's electricity consumption: A sectoral decomposition analysis. Applied Energy , 88 (12), 4779-4784.

[2] Mail and Guardian Online. (2008, August 26). Nersa: Power crisis costs South Africa about R50 billion. Retrieved March 30, 2009, from http://mg.co.za/article/2008-08-26-nersa-power-crisis-costsa-about-r50bn

[3] Center for American Progress. (2008, January 16). Cap and Trade 101. Retrieved March 30, 2009, from Center for American Progress: http://www.americanprogress.org/issues/2008/01/capandtrade101.html

[4] Schmalensee, R., Joskow, P., Ellerman, D., Montero, J., \& Bailey, E. (1998). An interim evaluation of Sulphur Dioxide emissions trading. Journal of economic perspectives , 12 (3), 53-68. 
[5] Klepper, G., \& Peterson, S. (2004). The EU emisions trading scheme allowance prices, trade flows and competitiveness effects. European Environment, 14 (4), 201-218.

[6] Profeta, T., \& Daniels, B. (2005). Design principles of cap and trade system for greenhouse gas gases. Duke University: Nicholas Institute for Environmental Policy Solutions.

[7] Ellerman, D. (2007). Forum: US experience with emissions trading . Cesito DICE Report 4.

[8] APX. (2008). Cap-and-trade: From all sides now. Retrieved March 30, 2009, from http://www.apx.com

[9] Stavins, R. (2008). Addressing climate change with a comprehensive US cap-and-trade system. Oxford Review of Economic Policy, 24 (2), 298-321.

[10] Braun, M. (2009). The evolution of emissions trading in the European Union- The role of policy networks, knowledge and policy entrepreneurs. Accounting, Organisations and Society , 34 (3-4), 469-487.

[11] Ellerman, D. (2009). The EU's emissions trading scheme: A prototype global system? Science and Policy global change reports.

[12] Shammin, M., \& Bullard, C. (2009). Impact of cap-and-trade policies for reducing greenhouse gas emissions on US households. Ecological Economics , 68 (8-9), 2432-2438.

[13] Edelston, B., Armstrong, D., Kirsch, L., \& Morey, M. (2009). Electricity price impacts of alternative greenhouse gas emission cap-and-trade programs. The electricity journal , 22 (6), 37-46.

[14] Michel, S. (2009). A cheap and effective CO2 cap-and-trade for electricity . The electricity journal , $22(8), 45-54$.

[15] Fell, H., Mackenzie, I., \& Prizer, W. (2008). Prices versus quantities versus bankable quantities. RFF Discussion paper No08-32-Rev .

[16] Blignaut, J., Koch, S., Riekert, J. I.-L., \& Nkambule, N. (2011). The external cost of coal-fired power generation: The case of Kusile. Pretoria: Greenpeace. 
[17] Hahn, R.W., Stavins, R.N. (2010). The effect of allowance allocations on cap-and-trade system performance. NBER Working paper No. 15854.

[18] IEA (International Energy Agency). (2001). International emission trading from concept to reality. Paris: IEA (International Energy Agency).

[19] Mohr, P., \& Fourie, L. (2008). Economics for South African students. Pretoria: Van Schaik publishers.

[20] Andrade-Silva, F., \& Guerra, S. (2009). Analysis of the energy intensity evolution in the Brazilian industrial sector-1995 to 2005. Renewable and Sustainable Energy reviews , 13 (9), 2589-2596.

[21] Markandya, A., Pedroso-Galinato, S., \& Streimikiene, D. (2006). Energy intensity in transition economies: Is there convergence towards the EU average? Energy Economics , 28 (1), 121-145.

[22] OECD (Organisation for Economic Co-operation and Development). (2009). Energy Balances for OECD countries. Paris: OECD (Organisation for Economic Co-operation and Development).

[23] OECD (Organisation for Economic Co-operation and Development). (2009). Energy balances for non-OECD countries. Paris: OECD (Organisation for Economic Co-operation and Development).

[24] IMF (International Monetary Fund). (2010 ). World Economic Outlook April 2010. Washington: IMF (International Monetary Fund).

[25] Goulder, L.H., Hafstead, M.A.C., Dworsky, M. (2010). Impacts of alternative emissions allowance allocation methods under a federal cap-and-trade program. Journal of Environmental Economics and Management, 60(3), 161-181.

[26] Hanemann, M. (2010). Cap-and-trade: a sufficient or necessary condition for emission reduction?. Oxford Review of Economic Policy, 26 (2): 225-252. 